\title{
Biometric models and maize genetic breeding: A review
}

\author{
Ivan Ricardo Carvalho* ${ }^{1}$, Vinícius Jardel Szareski ${ }^{1}$, Ritieli Baptista Mambrin ${ }^{3}$, Maurício Ferrari ${ }^{1}$, Alan Junior \\ Pelegrin ${ }^{1}$, Tiago Corazza da Rosa ${ }^{1}$, Márcio Peter ${ }^{1}$, Diógenes Cecchin Silveiraa ${ }^{2}$, Giordano Gelain Conte ${ }^{1}$, \\ Mauricio Horbach Barbosa ${ }^{1}$, Velci Queiróz de Souza ${ }^{4}$
}

\author{
${ }^{1}$ Universidade Federal de Pelotas, Capão do Leão, Rio Grande do Sul, Brazil \\ ${ }^{2}$ Universidade de Passo Fundo, Rio Grande do Sul, Brazil \\ ${ }^{3}$ Universidade Federal de Santa Maria, Rio Grande do Sul, Brazil \\ ${ }^{4}$ Universidade Federal do Pampa, Dom Pedrito, Rio Grande do Sul, Brazil
}

*Corresponding authors: carvalho.irc@gmail.com

\begin{abstract}
Genetic variability is essential for maize breeding, being source of determining alleles and genes that maximize traits of agronomic interest, minimize abiotic and biotic stresses, as germplasm sources for breeding, one can use landraces, adapted populations, exotic populations and commercial hybrids, which are readily available to lineages extraction and improved open pollinated varieties (OPVs). Thus, the aim of this review is to highlight the main dynamics involved in the genetic improvement of maize, the use of biometric models to select genotypes superior to grain yield and nutritional components. In this study it was possible to contextualize on: Botanical description, morphological and physiological characteristics, the genetic breeding, development of inbred lines, development of hybrids, variance components and genetic parameters, heterosis, diallel analysis, genotype $x$ environment interaction, associations between traits and Restricted Maximum Likelihood and Best Linear Unbiased Predictor (REML / BLUP).
\end{abstract}

Keywords: Biometrics, selection criteria, nutritional quality of grains, characters of agronomic interest.

\section{Introduction}

Maize (Zea mays L.) has its origin in the Central America, specifically from Mexico, and archaeological studies in the Tehucan Valley report that the first cultivations of this cereal occurred around 7000 BC (Bertolini et al., 2005). Some theories, based on molecular studies and genetic distances, were developed with the purpose of elucidating the emergence of this species, indicating that maize is a descendant of the species Zea mays spp. parviglumis (Doebley and Stec, 1993), commonly known as Teosinte, and originated in southern Guatemala, presenting cytogenetic similarities with some allelic differentiations. Maize is characterized as diploid with basic genome composed by ten $(2 n=2 x=20)$ chromosomes (Doebley, 1990; Parterniani and Campos, 1999). This species was benefited by a long period of domestication executed by pre-Columbian folks, allied to the great adaptive capacity, allowed maize to quickly spread throughout the American continent, making it possible to increment its genetic variability (Teixeira, 2008)

The large period of domestication allowed maize to increase its genetic variability and the emergence of new allelic constitutions, also the several cycles of cultivation with involuntary and/or directed selections resulted in the increment of favorable alleles for agronomic characteristics (Garbuglio et al., 2009). These traits' phenotypic expression is determined by the genetic constitution and environment effects (Allard, 1971). Therefore, the differentiations in maize populations may be based on the maturation periods, plant morphology and physiology, genetic, and cytological attributes, and purpose of utilization (Harlan, 1992).

Genetic variability is essential for maize breeding, being source of determining alleles and genes that maximize traits of agronomic interest, in the same way, to minimize abiotic and biotic stresses which may affect maize growth and development (Lima et al., 2000). As germplasm sources for breeding, one can use landraces, adapted populations, exotic populations and commercial hybrids, which are readily available to lineages extraction and later development of, as well as improved open pollinated varieties (OPVs).

Genetic progress in a maize breeding program is achieved through the search for populations with higher frequency of heterozygous loci for traits of interest, increasing the likelihood of achieving promising lines (Lima et al., 2000). Researches have evidenced the potential of landraces and open-pollinated varieties as germplasm for maize breeding pointing at cycle (Nardino et al., 2016), grain yield components (Baretta et al., 2016; Ferrari et al., 2018), bioactive compounds and micronutrients in maize seeds (Carvalho et al., 2018). Thus, the aim of this literature review is to highlight the main dynamics involved in the genetic 
improvement of maize, the use of biometric models to select genotypes superior to grain yield and nutritional components.

\section{Botanical description}

Maize belongs to the Plantae kingdom, Magnoliophyta division, Liliopsida class, Poales order, Poaceae family, Panicoideae subfamily, Maydeae tribe, Zea genus, and Zea mays L. species, presenting $2 \mathrm{n}=2 \mathrm{x}=20$ chromosomes (Paterniani, 1978; Paterniani and Campos, 1999; Castro et al.,1999). Published studies recognize five species of the Zea genus, being them: Zeadiploperennis; Zeaperennis; Zealuxurians; Zeanicaraguensise; and Zea mays L., and the four recognized subspecies of the Zea mays L. are: Zea mays L. ssp. huehuetenangensis; Zea mays L. ssp.mexicana; Zea mays L. ssp.parviglumis; and the cultivated maize Zea mays L. ssp. Mays (Buckler and Stevens, 2006).

\section{Morphological and physiological characteristics}

Maize plants present annual cycle, erect growth habit, plant height ranging between 1 and 4 meters. The radicular system may spread from 1.5 to 3 meters long. The roots are seminal (primary) and lateral (adventitious), its stem is cylindrical, formed by rigid nodes and internodes with dense interior. The leaves are alternately arranged around the stem, and they present parallel ribs with a rigid stripe in the center, the leaf blade is long, broad and flat with presence of hair and ligule (Paterniani, 1978).

Maize is a monoecious and cross pollination species. The inflorescences are spatially and temporally separated, the male inflorescence is located at the plant apex and is called panicle (tassel) with or without ramifications. In this structure are present the spikelet pairs. Each spikelet presents two flowers and three stamens, where they adhere to the anthers responsible for pollen formation, retention and release. The female inflorescence is formed by a rigid rachis (cob) that accommodates many pairs of spikelet, which are composed by the pistil and the basal ovary. Maize presents protandric behavior, and the pollen is released between 2 to 3 days before the viability of the stigmas in the female inflorescence. Under optimal conditions, the pollen is viable for up to 24 hours after being released by the anthers, its dispersion occurs through the wind (anemophilic) and may last from 2 to 14 days (Paterniani, 1978).

The fruit is called caryopsis and consists of endosperm (85\%), embryo (10\%) and pericarp (5\%) (Paterniani, 1978). Maize grains have around $62.4 \%$ of starch, $8.2 \%$ of crude protein, $3.6 \%$ of lipids and $1.2 \%$ of mineral material (Rostagno, 2011). Researches have shown that maize protein contains $7.8 \%$ of alanine, $3.6 \%$ of arginine, $2.9 \%$ of glycine, $10.0 \%$ of proline, $4.2 \%$ of serine, $3.1 \%$ of threonine, $0.31 \%$ of tryptophan and $1.9 \%$ of methionine (Borém and Rios, 2011).

Physiologically, maize presents C4 metabolism as carbon fixation strategy for photosynthetic processes. It culminates in the need of developing high leaf area and being highly efficient in intercepting photosynthetically active radiation (Magellan et al., 2002). Maize responds to the accumulation of growing degree days to determine the transitions from vegetative to reproductive phenological stages, besides, it directly influences the cycle duration (Nardino et al., 2016).
Maize is highly dependent on water for its physiological processes and tissues cooling, with water requirement of approximately $650 \mathrm{~mm}$ throughout the entire cycle (Bergamachi et al., 2001; Carvalho et al., 2013).

\section{The genetic breeding}

The researches involving maize genetic breeding were essential for the crop's progress, both in the agricultural and economic scope. The first studies with hybrid maize were conducted by Beal (1880) aiming to increase grain yield through hybridization among open pollinated varieties, verified that intervarietal hybrids presented superiority to their parents. Later, Shull (1909) developed studies on quantitative traits with particular interest in the number of spikes. This researcher postulated that breeding should not obtain the best lineage, but seeks for the superior hybrid combination among available lines.

Furthermore, he developed a scheme to obtain maize hybrids till used nowadays, where pure lineages were obtained through several successive self-fertilizations until homozygosity, then all the possible crosses are made, the obtained $F_{1 s}$ were evaluated, enabling the selection of the best combinations of lineages. The preliminary studies of East (1908) aimed at identifying the effects of endogamic depression as a function of self-fertilization and hybridization in maize. This researcher believed that the method of obtaining pure lines was correct, however, not commercially viable (Paterniani, 1978).

In 1919, Wallace was the first breeder of a private institution to achieve maize endogamiclines, however, it was Jones (1918) who suggested double-cross hybrids produced through crossing two single-cross hybrids, involving four inbred lines in their genetic base. His perception improved the viability of seed production on commercial scale. These joint efforts made it possible to introduce hybrid maize in the Corn Belt region of the United States, where the first commercial hybrids emerged in 1930, gradually minimizing the use of open pollinated varieties. In $1939,75 \%$ of the area in this region was already sown with hybrids. In 1960, less than $5 \%$ of the agricultural area was sown with open pollinated varieties. In Brazil, hybrid maize was introduced in 1943 through research from the Agronomic Institute of Campinas (Paterniani, 1978).

\section{Development of inbred lines}

Many types of hybrids may be obtained in maize breeding programs. However, a significant fraction is attributed to those derived from the combination of inbred lines. Therefore, obtaining these lineages becomes an essential practice and must be based on the specific interests of the responsible breeder. First of all, sources of genetic variability with potential to extract promising lines are identified and selected. Breeding programs are initiated by the selection of populations with favorable alleles of interest, this germplasm may come from landraces or populations obtained by self-fertilization of commercial hybrids, gathering favorable genes already established, which result in a greater efficiency to the breeding program (Amorim and Souza, 2005).

After the decision of which will be the populations used to lineages extraction, the breeder must decide the agronomic 
ideotype that will be prioritized to proceed with plants selection (individuals) in each population, being possible to perform a self-fertilization (Hallauer et al., 1988). The characteristics prioritized are related to cycle, foliar architecture, stem, tassel and ear dimensions, incidence of pests and diseases (Paterniani, 1978). Hallauer et al. (1988) defines that the best genetic gains in maize breeding are obtained when populations with greater genetic variability are used, thereby increasing the probability of gathering favorable alleles in the selected lineage. Thus, it is proceeded a self-fertilization of the selected plant $\left(\mathrm{S}_{0}\right)$ by protecting the main spike before stigma exteriorization using a waterproof paper or plastic bag (Paterniani, 1978; Hallaueret al., 1988).

After the inflorescence (tassel) exteriorization and the beginning of pollen release, this structure is protected with an impermeable paper bag in order to collect as much pollen as possible. When the stigmas are externalized, the collected pollen should be directed to the stigma receptacles, remaining the spikes protected until the moment of harvest (Paterniani, 1978).

Therefore, the first self-fertilization cycle $\left(S_{1}\right)$ is completed. These procedures are performed until the lineage becomes completely inbred and homozygous. The breeder, on field conditions, visualizes the phenotypic expression of the traits of interest, and when the homogeneity of plants in a line is identified, it is considered a pure line. Hallauer et al. (1988) defines the theoretical proportions of homozygotes along generations of self-fertilization and required to obtain inbred maize lines, being the $S_{0}$ generation: $0.0 \%$ homozygous, $\mathrm{S}_{1}: 50.0 \%$ homozygous, $\mathrm{S}_{2}: 75.0 \%$ homozygous, $\mathrm{S}_{3}: 87.5 \%$ homozygous, $\mathrm{S}_{4}: 93.8 \%$ homozygous, $\mathrm{S}_{5}: 96.9 \%$ homozygous, $\mathrm{S}_{6}$ : $98.4 \%$ homozygous and $\mathrm{S}_{7}$ : $99.9 \%$ homozygous.

\section{Development of hybrids}

Since the pioneering works of Beal (1880), Shull (1908-1910), East (1908) and Jones (1918), the performance of maize hybrids is considered to be superior to their respective parents, being them either open pollinated varieties or inbred lines. In this way, the efficient choice of the population to be improved, the selection of promising lines, the inbred benefits of pure lines, and the heterosis effects obtained as result of hybridization of allelic distinct genitors, enable genetic gains in maize breeding. Considering it, by employing different hybridization strategies it is possible to synthetize a large variety of hybrids which vary in the genetic basis, productive potential, genetic and phenotypic uniformity, adaptability as well as environment requirements (Paterniani, 1978; Hallauer et al., 1988).

The maize breeding techniques presented by Viégas and Miranda Filho (1978), and Nardino et al. (2016) allowed to synthetize the following types of hybrids:

Top Cross Hybrid - based on the cross between inbred lines and a common parent with broad genetic basis. This type of hybrid does not have a commercial appealing, but is largely utilized in breeding programs for lineages evaluation.

Single-Cross Hybrid - produced by crossing two inbred lines, it generally presents higher productivity and uniformity when compared to other hybrids.

Modified Single-Cross Hybrid - a female parent (hybrid) is originated from two progenies from the same inbred line (A $\left.x A^{\prime}\right)$, then it is crossed with other inbred line (B). Its major advantage is a higher female parent's vigor by incrementing seeds productivity.

Triple-Cross Hybrid - obtained by crossing a simple-cross hybrid with a third inbred line.

Double-cross Hybrid - Achieved by the crossing between two single-cross hybrids involving four endogamic lines.

Multiple Hybrid or Compost - it originates from six, eight or even more inbred lines, and presents little commercial relevance, in contrast, it keeps greater genetic variability with better adaptation under adverse environmental conditions.

Intervarietal Hybrid-achieved through crosses between open pollinated varieties (VPAs). It allows exploring the effects of intervarietal heterosis, and reveals a broad genetic base and a higher environment adaptive value. This hybrid can be easily obtained and used on commercial scale.

A maize breeding program begins with the definition of its goals, the selection of populations, the development of inbred lines, followed of crosses guided by genetic designs that reveal the best hybrid combinations, and posteriorly, VCU assessments (value for cultivation and use) to compare the best hybrids in different environments and agricultural years (Viégas and Miranda Filho, 1978). Regarding the dynamics involved in maize breeding, many techniques and strategies are used to reveal reliable inferences aiding the selection of the best inbred lines, hybrids and traits of interest. Therefore, biometric models allowto infer and predict essential parameters for selecting, conducting and achieving superior genotypes through genetic breeding.

\section{Variance components and genetic parameters}

Genetic breeding bases its conducting and selecting strategies on phenotypic measures of the traits of interest. However, the phenotypic value is due to additive and nonadditive genetic effects, and environment effects. Most traits of agronomic interest are quantitative and present continuous distribution, determined by a large number of genes, with low heritability and highly influenced by the environment (Falconer, 1981). The responsible traits for the continuous distribution and different phenotypic classes are influenced by the genotype's characteristics, the environment and the interaction of these factors. Furthermore, the expressed phenotypic magnitudes are due the inheritable and non-inheritable effects (Mather and Jinks, 1984).

The inheritable nature of a trait is determined by the additive genetic variance present in that generation. This component of variance is based on the degree of similarity between parents and progeny, corresponding to the average effect of these alleles which influence genic frequency and enable effective responses through selection (Falconer, 1981). It is defined that variance components are variances associated to random effects, i.e., treatment factors of a mathematical model (Barbin, 1993). Researches have shown that genetic gains in maize population breeding were obtained by basing the selection in the additive genetic variance (Pacheco et al., 1998). Quantitative genetics studies used the additive genetic variance to obtain superior intervarietal genotypes through reciprocal recurrent selection (Junior et al., 1993). The additive genetic component was essential to identify the inheritable nature 
of dimensions, bioactive compounds and micronutrients of maize seeds (Carvalho et al., 2016).

The non-inheritable effects expressed by a trait are related to deviations of dominance (allelic interaction) and epistatic (gene interaction) genes, which are influenced by a few loci orby the interaction of these loci (additivity or dominance), and by the effects of environment (Falconer, 1981). The dominance and epistasis can result in the low relation of the inbred line with the hybrid. This biological phenomenon may cause errors in the selection of superior genotypes, where the greater evidences are attributed to epistasis because it is more complex, to contribute for traits inheritance and population dynamics (Hallauer et al., 1988). Studies have identified different contributions of the additive, dominance and epistatic effects on the expression of resistance to phaeosphaeria leaf spot in maize (Pegoraro et al., 2002).

The estimation of the genetic parameters is essential for maize breeding, where heritability represents the inheritable genetic ratio attributed to the genes' average effect as function of the trait's total variation, revealing the similarity between progenies and the predictive capacity for the next generation, in practical conditions the phenotype is measured, even though the breeder's interestis the genetic value (Falconer, 1981; Mather and Jinks, 1984). Studies indicate that heritability is characterized as the degree of correspondence between the progeny genotype and the breeding value of a trait, for the quantitative trait its magnitude is low due to the actions of dominance, epistasis and environmental effects (Hallauer et al., 1988).

The direction of heritability is determined by the genetic variance used in the estimates (Hallauer et al., 1988). In this way, broad sense heritability $\left(\mathrm{H}^{2}\right)$ comes from the ratio between the total genetic variance (additive, dominance and epistatic effects) and the phenotypic variance of the trait (Mather and Jinks, 1984). Narrow sense heritability $\left(h^{2}\right)$ is defined by the ratio between the additive genetic variance and the phenotypic variance of the character (Falconer, 1981). For maize genetic breeding, Hallauer et al. (1988), classified heritability as high $\left(\hat{h}^{2}>70\right)$, medium or intermediate $\left(30<\hat{h}^{2}<70\right)$ and low $\left(\hat{\mathrm{h}}^{2}<30\right)$.

The broad sense heritability $\left(H^{2}\right)$ is achieved through the following equation (Ramalho et al., 2012):

$$
H^{2}=\frac{\sigma^{2} G}{\sigma^{2} P}
$$

Where: $\sigma^{2} G=$ Genetic variance and $\sigma^{2} P=$ Phenotypic variance.

The narrow sense heritability $\left(h^{2}\right)$ is achieved through the following equation (Ramalho et al., 2012):

$$
h^{2}=\frac{\sigma^{2} A}{\sigma^{2} P}
$$

Where: $\sigma^{2} A=$ Additive genetic variance and $\sigma^{2} P=$ Phenotypic variance.

Research conducted by Nardino et al. (2016) reveal broad sense heritability for spike length $\left(H^{2}: 0.70\right)$, spike mass $\left(H^{2}\right.$ : $0.65)$, spike grain mass $\left(H^{2}: 0.62\right)$, cob mass $\left(H^{2}: 0.70\right)$ and grain yield $\left(H^{2}: 0.23\right)$. Similarly, Soares et al. (2000) and Baretta et al. (2016), estimated this parameter for mass of one hundred grains $\left(\mathrm{H}^{2}: 0.60\right.$ and 0.87$)$, respectively. Carvalho et al. (2016), verified narrow sense heritability for mass of a thousand grains $\left(h^{2}: 0.06\right)$, grain length $\left(h^{2}: 0,11\right)$, grain width $\left(h^{2}: 0,19\right)$, sodium content in the grains $\left(h^{2}\right.$ : $0,34)$, soluble solids $\left(h^{2}: 0,25\right)$, total flavonoids $\left(h^{2}: 0,08\right)$, total carotenoids $\left(h^{2}: 0,48\right)$, antioxidant potential by the DPPH radical $\left(h^{2}: 0,26\right)$ and ABTS $\left(h^{2}: 0.07\right)$, Palomine et al. (2000) verified $h^{2}: 0.25$ for grain yield.

\section{Heterosis}

It is characterized as being a biological phenomenon widely exploited by maize genetic breeding. Studies by East (1936) and Shull (1912) defined heterosis as the vigor increment of the progeny when compared to their respective parents. Heterosis may be obtained by crossing genetically distant genitors or based on heterotic patterns, which are composed by genitors with pre-stablished characteristics that increase specific traits through the cross (Hallauer et al., 1988).

Heterosis $\left(\mathrm{H}^{+} \%\right)$ is achieved by the following equation (Ramalho et al., 2012):

$$
H^{+}(\%)=\frac{\left(F 1-\left(\frac{G 1+G 2}{2}\right)\right)}{\left(\frac{G 1+G 2}{2}\right)} \times 100
$$

Where: $\mathrm{H}^{+}=$percentage of heterosis, $F 1=$ trait's magnitude in the progeny, $G 1=$ trait's magnitude in the female genitor and $G 2$ = trait's magnitude in the male genitor.

The genetic basis of heterosis is sustained by theories that consider the degree of dominance, the accumulation of favorable alleles in partial dominance, and the multiple response of alleles in a locus (East, 1936; Shull, 1912). Studies evidence the contributions of allelic interactions and over dominance (Hull. 1945), influence of the number of genes, allelic frequency and dominance level (Bruce, 1910) may be based in the accumulation of favorable genes in dominance located in different loci (Jones, 1945).

In this context, the importance of heterosis was emphasized in researches that used inbred lines to develop hybrids, giving emphasis to the main components of grain yield (Paterniani et al., 2008; Nardino et al., 2016), for developing hybrid combinations resistant to Puccinia polysora (Da Silva et al., 2001). Likewise, the intervarietal heterosis was used to increase dimensions, bioactive compounds and micronutrients in maize seeds (Carvalho et al., 2016), as well as the physiological quality of seeds (Reis et al., 2011).

\section{Diallel analysis}

The biometric inferences verified through the diallel analysis are due to the use of genetic designs that allow extracting crucial information to the breeder. Dialelic crosses aim to recombine the genetic variability available in the breeding program and to obtain progenies with the genetic constitution of both parents, where they may be superior or inferior to their respective parents (Hallauer et al., 1988). The parents with potential to integrate a crossing scheme in a diallel should differ their alleles at certain locus. Thus, genotypic and phenotypic modifications can be obtained in the progeny (Mather and Jinks, 1984).

The diallel approach is widely used in maize breeding programs because they provide inferences about reciprocal crosses, they also reveal the most suitable maternal or paternal parents, detail whether there is presence of inheritance or maternal effect for the trait of interest, allow to comprehend the gene action involved, reveal which line or variety is the most suitable to be used as a parent, and 
explore the effects of heterosis and combining ability (Hallauer et al., 1988; Falconer, 1981; Nardino et al, 2016).

Combining ability is attributed to the variation caused by the crossing effects and can be explained by the general combining ability (GCA), which consists in the average performance of the parents and their deviation from the general average, being defined by the additive genetic variance. However, the specific combining ability (SCA) is characterized by the deviation of the crossed in relation to the expected by their parents (GCA), based on non-additive genetic effects of dominance, over dominance and epistasis (Vencovsky, 1978; Falconer, Hallauer et al., 1988). Thus, it is desired that at least one of the genitors involved in the SCA presents a high GCA (Bordallo et al., 2005). The combining ability in maize is influenced by the genitor's characteristics, growing environment, genic and allelic interactions (Nardino et al., 2016). The SCA for a quantitative trait is dependent on the deviations of dominance, epistatic effects, heterozygosis and presence of favorable alleles (Hallauer and Miranda Filho, 1995).

\section{Genotype $x$ environment interaction}

The phenotypic variation is composed by additive and nonadditive genetic effects, action of the growing environment $(E)$, and genotypes $x$ environments $(G \times E)$. Therefore, in order to identify and quantify the effects of $G \times E$ interaction, the presence of at least two genotypes grown in two environments is essential (Mather and Jinks, 1984; Cruz et al., 2014; Santos et al., 2018). Maize genetic breeding usually prioritizes traits controlled by a large number of genes characterized as quantitative of continuous distribution (Hallauer and Miranda Filho, 1995). Considering it, higher are the influence of $G \times E$ interaction in the economic and agricultural scope, as these traits express random responses originated in the genotype's sensitivity to abiotic and biotic variations of the growing environment (Lynch and Walsh, 1998).

The $G \times E$ interaction directly influences genetic breeding through strategies of conducting and selecting progenies (Nunes et al., 2002), disturbing the measurements and precision of the inferences (Alliprandini et al., 1994), and increasing the financial resources and time spent to achieve genetic gains for the desired traits (Pereira et al., 2016). Research evidences that the genetic basis is closely related to the genotype's response to $\mathrm{G} \times \mathrm{E}$ interaction, being the single-cross hybrids the most responsive to these modifications (Costa et al., 2010; Szareski et al., 2018). Therefore, the highest effects are revealed in competition and evaluation trials of maize hybrids (Ribeiro and Almeida, 2011).

By identifying the presence of $G \times E$ interaction for a given trait, it becomes necessary to understand the nature of this phenomenon, where the phenotypic manifestations verified might be derived from the simple interaction, characterized when the genotypes do not change their tendencies within a set of environments, the differences evidenced are only in the trait's magnitude (Szareski et al., 2017). In contrast, the complex interaction is due to the low contribution of the genetic fraction for the genotype's phenotypic expression among the tested environments, being the variations of environment more relevant for the trait's direction and magnitude. Researches define that the simple interaction reveals elevated genotypic correlation among environments (Pupin et al., 2015). However, in case of lower genetic contribution to the phenotype in different environments, it results in the complex interaction with less phenotypic stability for the trait (Rosado et al., 2012; Carvalho et al., 2018).

Plant breeding aims at gathering all necessary alleles for and ideal phenotypic expression in the same genotype. Thus, breeding strategies are based on the agronomic ideology and on the peculiar needs of the agricultural environment (Paterniani, 1978). According to Eberhart and Russel (1966), an ideal genotype must evidence a high average of the desired traits, phenotypic stability, tolerance to unfavorable environments, and respond to the growing environment improvement (Cruz et al., 2012).

Research by Lynch and Walsh (1998) defined the phenotypic plasticity as the phenotype modifications due to the environment effects. On the other hand, the phenotypic stability refers to the quantitative tendency constantly evidenced in the phenotypic expression in different environments. Cruz et al. (2012) determined that phenotypic stability is based on the ability of the genotype to demonstrate predictable behavior due to environmental stimulation, however, adaptability regards the genotype's ability of advantageously benefiting from stimulus of the environment where they are grown.

In this context, the $\mathrm{G} \times \mathrm{E}$ interaction may be an obstacle to genetic breeding, being necessary the comprehension of concepts and use of biometric methodologies to recommend which environments are considered favorable or unfavorable, and also to indicate the best genotypes. Based on these needs, the Annicchiarico's method (1992) reveals the genotype's stability in relation to the trait's average for each tested environment, where the results are based on the estimation of a confidence index for each genotype, which allows to infer which genotype is superior and which environments are favorable or unfavorable to the traits of interest (Cruz et al., 2014).Researches emphasize the Annicchiarico's method importance to define which environments were considered favorable or unfavorable for maize grain yield (Cargnelutti Filho et al., 2007; Cargnelutti Filho et al., 2009), otherwise, research by Carvalho et al. (2016) used this technique to define the best single-cross hybrids and growing environments for the percentage of crude protein in maize grains.

\section{Associations between traits}

Many traits of interest to genetic breeding are associated, thereby, biometric methodologies are applied in order reveal these interrelations and estimate phenotypic $(\mathrm{rP})$, genetic $(r G)$ and environmental $(r E)$ correlation coefficients (Lynch and Walsh, 1998). The linear correlation evidences the tendency of association between two traits, and the interpretation of its magnitude and direction must be cautious. However, understanding these associations allows the breeder to reveal which correlations are due to genetic effects (pleiotropy and linkage), and which may modify the selection dynamics in breeding programs, as well as to understand whether the environment can act on the trait's adaptive value (Falconer, 1981).

The genetic causes are related to pleiotropy, where a single gene simultaneously affects two or more traits (Falconer, 
1981). However, genetic linkage is due to genes physically close that can segregate together, being a transient and unstable phenomenon (Churata et al., 1996). However, environment correlation is intended to indicate the direction of the environment effects in the linear association for both traits (Falconer, 1987). When the directions of genetic and environment coefficients are opposite, it becomes an indication that genetic and environmental variations distinctly influence the trait (Falconer, 1987). Researches evidence that the coefficient of phenotypic correlation ( $r P$ ), when inferior to the genetic coefficient $(r G)$, indicates that the phenotypic manifestation is superiorly controlled by genotypic effects, and its interpretation may be used for selecting because it presents greater reliability and efficiency (De Gonzáles et al., 1994).

The phenotypic correlation ( $\mathrm{rP}$ ) is achieved by the following equation (Cruz et al., 2012; Ramalho et al., 2012):

$$
r_{F}=\frac{C O V_{x y}}{\sqrt{\sigma_{P(x)}^{2} \cdot \sigma^{2}{ }_{P(y)}}}
$$

Where: rP: Coefficient of phenotypic correlation, COVxy: Phenotypic covariance between the $\mathrm{x}$ and $\mathrm{y}$ traits; ${ }^{2} P(x)$ : phenotypic variance of the $\mathrm{x}$ trait; $\sigma^{2} P(y)$ :Phenotypic variance of the $y$ trait.

The genetic correlation ( $\mathrm{rG}$ ) is achieved by the following equation (Cruz et al., 2012; Ramalho et al., 2012):

$$
r_{G}=\frac{\operatorname{COV} G(x y)}{\sqrt{\sigma_{G(x)}^{2} \cdot \sigma_{G(y)}^{2}}}
$$

Where: rG: Coefficient of genetic correlation, COVxy:Genotypic covariance between the $\mathrm{x}$ and $\mathrm{y}$ traits; ${ }^{2} G(x)$ : Genotypic variance of the $\mathrm{x}$ trait; $\sigma^{2} G(y)$ :Genotypic variance of the $y$ trait.

The environment correlation $(\mathrm{rE})$ is achieved by the following equation (Cruz et al., 2012; Ramalho et al., 2012):

$$
r_{E}=\frac{\operatorname{COV} E(x y)}{\sqrt{\sigma_{E(x)}^{2} \cdot \sigma_{E(y)}^{2}}}
$$

Where: rA: Coefficient of environment correlation, COVxy: Environmental covariance between the $\mathrm{x}$ and $\mathrm{y}$ traits; ${ }^{2} G(x)$ : Environment variance of the $\mathrm{x}$ trait; $\sigma^{2} G(y)$ : Environment variance of the $y$ trait.

The linear correlations are essential for breeding, since they allow understanding the magnitude and sense of the phenotypic and genotypic associations of morphological traits, tassel dimensions and yield components of maize (Nardino et al., 2016). Phenotypic inter-relationships were performed for spike and grain dimensions of single, double and triple cross hybrids (Lopes et al., 2007). A study carried out in five growing environments in Southern Brazil used 27 maize hybrids, where they characterized the importance of phenotypic, genotypic and environmental correlation coefficients to obtain efficient indirect selection responses in order to increase the number of grains per spike (Nardino et al., 2016).Studies with families of half-siblings derived from a compost maize hybrid proved the efficiency of the associations between traits, when gathering inferences of phenotypic, genotypic and environmental linear correlation along the path analysis (Churata and Ayala-Osuma, 1996).

The path analysis was described by Wright (1921) and used in (1923), providing a better understanding of the associations between traits by slicing the simple correlations (Li, 1975). This methodology allowed quantifying the strength and direction of associations between complex traits, revealing the importance of direct and indirect effects on the dependent trait (Cruz et al., 2012). This analysis allows determining the cause and effect interrelationships for the studied traits, in genetic breeding it is commonly used to determine the importance of primary and secondary traits of the crop, guiding the indirect selection of promising genotypes through traits of agronomic interest (Cruz et al., 2012). For Nogueira et al. (2012), the understanding of the associations between traits becomes essential for genetic breeding because it helps directing which selection strategy should be approached.

This method presents particularities and its coefficient reveals positive or negative direction, being a standardized coefficient that allows relating measured characters in different physical units and does not express notations in their results (Cruz et al., 2012). In genetic breeding programs, it is necessary to identify which traits present a higher correlation with the main trait, and the direct effect should have a favorable direction for selecting, in contrast, opposite directions between total correlation and direct effects indicate absence of cause and effect association (Cruz et al., 2006). Studies reveal that the indirect selection is feasible and may be executed for the traits of difficult measurement, low heritability and highly influenced by the growing environment (Cruz et al., 2004; Nardino et al., 2016).

The definitions of the associations allow the breeder to understand each trait's importance in the trait's phenotypic expression, because when the indirect selection is not based on other trait's effects, it can result in changes of undesirable characteristics (Santos et al., 2000). Ramalho et al. (1993) determined that the correlation and the interrelationships between traits were important to plant breeding since they determined the effect of the selection proceeded in a certain character, and its effects on the other traits of the crop.

Another biometric approach essential for breeding is the use of canonical correlations, which are based on the estimation of the maximum correlation between groups of traits (Cruz et al., 2012). This analysis minimizes the problems related to the presence of only one dependent trait, since it does not distinguish which traits are dependent or independent, but instead it reveals the maximum correlation between groups (Morrison, 1978). Cruz et al. (2005) reveals that this method allows analyzing the interrelationships between groups with a varied number of traits, where associations are easily explained through a few correlations (Cruz and Regazzi, 2004).

The associations between groups are possible through the presence of at least two traits of interest (Cruz et al., 2012), where the number of canonical correlations is equal to the number of traits forming the smallest group, and the strength of these correlations are inversely proportional to the order they were estimated (Cruz and Regazzi, 2006). Cruz et al. (2012) show that the statistical problem is linked to the maximum estimate of the linear correlation between groups, which determine a weighting coefficient in each linear correlation of the traits. These coefficient's estimations for the traits of interest facilitate the identification of promising genotypes, allowing using their results for indirect selection (Carvalho et al., 2015). According to Carvalho et al. (2004), the understanding of the 
relationships between traits allows to increase the selection efficiency, which directly reflects in the breeding program success. Santos and Vencovsky (1986) have shown that correlations identify associations between traits, where the selection of a given trait may influence the others. Therefore, the canonical correlation is beneficial for genetic breeding and provides an understanding of the associations between groups of traits of agronomic interest (Coimbra et al., 2000).

\section{Restricted Maximum Likelihood and Best Linear Unbiased Predictor (REML / BLUP)}

The principle of likelihood was developed by Fischer in 1922, assuming that the model is true and only the parameter's values need to be determined. Thus, the likelihood function provides an accurate measure of uncertainty and summarizes all the information that the data provide for an unknown parameter, its estimates are relative and not absolute. For large samples, the conventional methods approximate to results obtained by the likelihood, being an exact method independent of the sample size or the data distribution (Resende et al., 2014). Likelihood is a model that jointly considers the fixed and random effects, being called mixed model. In this context, the inferences taken for the fixed effects are defined as estimates. In contrast, for random effects, the correct term is prediction (Lynch and Walsh, 1998). Random effects are attributed to the variation factors referring to the representative sample of the population, on the other hand, fixed effects are attributed to variation factors delimited and restricted by pre-established levels (Barbin, 1993).

The maximum likelihood (ML) is based on achieving the point of maximum function, being defined as the joint probability density function for all experimental observations. However, as disadvantage, this model does not consider the loss of degrees of freedom due to the fixed effects estimation, which culminates in biased estimators (Resende et al., 2014). It is sought consistent, efficient estimators that meet the normal distribution, following the assumptions of non-bias, impartiality, and centered on the parameter itself. This estimator must have consistency with asymptotic property, and its value should not change due to the increase in sample size, it also must be efficient and reveal precision with minimum variance (Ceconet al., 2012). Considering the need of minimizing some imperfections attributed to the maximum likelihood (ML) method, studies by Patterson and Thompson (1971) developed the restricted maximum likelihood (REML), which eliminated the intrinsic bias of maximum likelihood, while maintaining the remaining properties of unbiased estimators and positive components. The REML approach allows to decompose the total variance obtained in a given experimental trial into components of variance, which are not influenced by the model's fixed effects and weighted by the degrees of freedom, providing unbiased and reliable estimators (Resende et al., 2014). The REML method reveals greater mathematical difficulty, however it enables to achieve the components of variance in situations where there is no normality and balanced data, allowing these estimates to be positive (Lynch and Walsh, 1998).

The knowledge of the genetic value of a given genotype is crucial for breeding. This value's prediction became possible since 1963 through Henderson's studies, which compiled in a single model, the least squares of Yates (1931) method, the selection indexes of Lush and Wright (1931) and the inferences obtained by the best linear predictor, being denominated asthe new best linear unbiased prediction (BLUP) model. These interactive computational techniques are commonly associated with the methodologies of mixed models (REML) for achieving the components of variance and genetic parameters (Cruz et al., 2014; Resende et al., 2014). The restricted maximum likelihood (REML), joined to the best linear unbiased predictor (BLUP), areused assuming that the components of variance are known and the genetic effects are considered random (Cruz et al., 2014). The REML /BLUP methodology maximizes the relation between the predicted and the true genetic value, minimizing prediction errors (Resende et al., 2014).

Researches employing mixed models methodologies (RELM / BLUP) were used in the selection of full-siblings progenies in popcorn (Freitas et al., 2013), to predict the efficient utilization of phosphorus in maize hybrids through a diallel analysis (1998), used to estimate the components of variance and genetic parameters of grain yield traits in maize (De Souza et al., 2015), in the prediction of genetic value of single-cross hybrids, (Baretta et al., 2016), and applied for selecting the best maize hybrids grown in different environments in southern Brazil (Nardino et al., 2016).

\section{Conclusion}

The success of any breeding program depends on the careful selection of new germplasm to incorporate into the selection work. The trend of modern agriculture requires increasingly uniform and high yielding genotypes. The high diversity of environments exploited by modern agriculture and the pressure by generation of genotypes able to produce adequately under several stress conditions generates the need to offer a growing set of improved genotypes to specific environmental conditions. The use of biometric tools is fundamental for researchers since it enables to evaluate with efficiency and effectiveness the characteristics desired by breeding programs.

\section{References}

Allard R W (1971) Principles of plant breeding. São Paulo: Edgard Blücher Ltda., 485p.

Alliprandini LF, De Toledo JFF, Fonseca JRN, De Almeida LA De Souza KRA (1994) Effects of genotype X Environment interaction on soybean yield in Parana State, Brazil. Braz J Agric Res. 29 (9): 1433-1444.

Amorim EP, Souza JC (2005) Evaluation of inter and intra populational maize hybrids from so progenies of commercial single cross hybrids. Bragantia. 64(30): 561567.

Annicchiarico P (1992) Cultivar adaptation and recommendation from alfafa trials in Northern Italy.J.of Gen.andBreed.1(46): 269-278.

Bardin D (1993) Componentes de variância: Teoria e aplicações. Piracicaba: FEALQ, 120p.

Baretta D, Nardino M, Carvalho IR, De Oliveira AC, De Souza VQ, Da Maia LC (2016) Performance of maize genotypes of Rio Grande do Sul using mixed models. Scientific. 44(3): 403-411. 
Baretta D, Nardino M, Carvalho I R, Danielowski R, De Souza H, Luche VFDO, De Souza VQ, De Oliveira AC, Da Maia LC (2016) Characterization of dissimilarity amongv arieties in Brazilian maize germplasm. Aust J Crop Sci. 1(12): 16011607.

Beal WJ (1987) In: Paterniani E, Viegas GP Melhoramento e Produção de Milho. Campinas: Fundação Cargill, 795p.

Bergamaschi H, Radin B, Rosa LMG, Bergonci Jl, Aragonés R, Santos AO, França S, Langensiepen M (2001) Estimating maize water requirements using agrometeorological data. Arg J Agromet.1(1): 23-7.

Bertolini M, Franchi R, Frisanco F (2005) II Unastoriaanchetrentina. Isntituto Agrariodi San Michele all'Adige.

Bordallo PN, Pereira MG, Amaral Júnior AT, Gabriel APC (2005) Diallel Analysis of sweet and regular corn genotypes for agronomic characters and total protein content. Braz. Horticul. 23(1): 123-127.

Borém A, Rios SA (2011) Milho Biofortificado.ed.1., v.1, 211p.

Brieger FG (1944) Experimental studies on the origin of maize. Anais da Escola Superior de Agricultura Luiz de Queiroz, 01: 225-277.

Bruce $A B(1910)$ The mendelian theory of heredity and the aumentation of vigor. Sci. 32: 627-628.

Buckler ES, Stevens NM (2006) Maize origins, domestication, and selection. In: Motley TJ, Zerega N, Cross H. Eds. New York: Columbia, cap. 4, 67-9p.

Cargnelutti Filho A, Perecin D, Malheiros EB, Guadagnin JP (2007) Comparison of methods for phenotypic adaptability and stability analysis in common bean. Bragantia. 66: 571578.

Cargnelutti Filho A, Storck L, Riboldi J, Guadagnin JP (2009) Association between adptability and stability methods in corn. Rur Sci. 39(2): 340-347.

Carvalho FIF, Lorencetti C, Benin G (2004) Estimativas e implicações da correlação no melhoramento vegetal. Pelotas: UFPel,142p.

Carvalho IR, Nardino $M$, Pelegrin AJ, Ferrari M, Demari GH, Szareski VJ, Barbosa M H, Souza VQ (2016) Path analysis and Annicchiarico method applied in relation to protein in corn grains. Aust J Bas Appl Sci. 10: 300-306.

Carvalho IR, Nardino M, De Pelegrin AJ, Hoffmann JF, Poleto SM, Ferrari M, Szareski VJ, Meira D, Chaves FC, De Souza VQ, De Oliveira AC, da Maia LC (2016) Estimate of genetic parameters in bioactive and micronutrientes compounds of maize. Afri J Agricul Res. 11(33): 3123-3133.

Carvalho IR, Szareski VJ, Demari GH, Barbosa MH, Conte GG, Souza VQ, Aumonde TZ, Villela FA, Pedo T (2018) Artificial Neural Network and Multivariate Models Applied to Morphological Traits and Seeds of Common Beans Genotypes. J Agric Sci. 10: 572-580.

Carvalho IR, Nardino M, Demari GH, Pelegrin AJ, Ferrari M, Szareski VJ, Oliveira VF, Barbosa MH, Souza VQ, Oliveira AC, Maia LC (2017) Components of variance and interrelation of important traits for maize (Zea mays) breeding. Aust Crop Sci. 11:982-988.

Carvalho IR, Souza VQ, Nardino M, Follmann DN, Schmidt D, Baretta D (2015) Canonical correlations between morphological traits and yield components in dualpurpose wheat. Braz J Agric Res.50(8): 690-697.
Carvalho IR, Pelegrin AJ, Ferrari M, Szareski VJ, Rosa TC, Oliveira VF, Hoffmann JF, Nardino M, Chaves FC, Souza VQ, Oliveira, AC, Maia LC (2018) Heterosis and genetics parameters for yield and nutritional components in halfsibling maize progenies. Genet Mole Res. 17: p. 1-12.

Castro PRC, Kluge RA (1999) Ecofisiologia de cultivos anuais. São Paulo: Ed. Nobel, 126p.

Cecon PR, Silva AR, Nascimento M, Ferreira A (2012) Métodos Estatísticos. 1. ed. Viçosa: Editora UFV v. 1. 229p.

Churata BG, Aylasuna JT (1996) Genetic, phenotipic and envitonmental correlations and path coeficiente analysis of traits in the maize (Zea mays L.). Ceres. 43: 249.

Coimbra JLM, Guidolin AF, Carvalho FIF, Azeved R (2000) Canonical correlations: II - Analisys of bean yield componentes. Rur Sci. 30(1): 31-35.

Costa EFN, De Souza JC, Lima JL, Cardoso GA (2011) Genotype by environment interaction in different types of maize hybrids. Braz J Agric Res. 45(12): 1433-1440.

Cruz CD, Regazzi AJ, Carneiro PCS (2012) Modelos Biométricos Aplicados ao Melhoramento Genético. Viçosa: Editora UFV, 1(4): 514.

Cruz CD, Regazzi AJ, Carneiro PCS (2004) Modelos biométricos aplicados ao melhoramento genético. 1. 3 ed. Viçosa: UFV, 480p.

Cruz CD,Regazzi A (1997) Modelos biométricos aplicados ao melhoramento genético. 2 ed. Viçosa: UFV. P390.

Cruz CD, Carneiro PCS, Regazzi AJ (2014) Modelos Biométricos Aplicados ao Melhoramento Genético, vol. 2. Viçosa, 3a Ed. Editora UFV.

Da Silva HP, Barbosa MPM, Nass LL, Camargo LEA (2001) Combining capacity and heterosis for resistance to Pucciniapolysora in maize. Sci Agric. 58(4): 777-783.

De González PA, Lemos MA, Neto CER, Dos Reis OV, Tabosa JN, Tavares JJ(1994) Genetic, phenotypic and environmental correlations in two cycles of selection in the "Dentado Composto" corn. Braz J Agric Res. 29(3): 419-425.

De Souza VQ, Baretta D, Nardino M, Carvalho IR, Follmann DN, Konflanz VA, Schmidt D (2015) Variance components and association between corn hybrids morpho-agronomic characters. Scientific. 43(3): 246-253.

Doebley J (1990) Molecular evidence for gene flow among Zea species. Bio Sci. 40(6): 443-448.

Doebley J, Stec A (1993) Inheritance of the morphological differences between maize and teosinte: comparison of results for two F2 populations. Genetics. 134(2): 559-570.

Dovale JC, Fritsche-Neto R (2013) Genetic control of traits associated with phosphorus use efficiency in maize by REML/BLUP. J Sci Agron. 44(3): 554-563.

East EM (1936) Heterosis. Genetics. 21(4): 375.

East EM (1908) Inbreeding in corn. Rep. Conn. Agric. Exp.Stn. 1907: 419-428.

Eberhart R, Russel WA (1966) Stability parameters for comparing varieties. Crop Sci. 6(1): 36- 40.

Falconer DS (1981) Introdução a Genética Quantitativa.1 ed. Londres: Longman Grup. 438p.

Falconer DS (1987) Introdução à genética quantitativa. UFV.

Ferrari M, Pelegrin AJ, Carvalho IR, Nardino M, Szareski VJ, Olivoto T, Rosa TC, Follmann D, Pegoraro C, Oliveira AC, Maia LC, Souza VQ (2018) Path analysis and phenotypic correlation among yield components of soybean using environmental stratification methods. Aust J Crop Sci. 12. p. 193-202. 
Freitas IL, Junior ATA, Viana AP, Pena GF, Cabral PS, Vittorazzi C, Silva TRC (2014) Genetic gain evaluated with selection índices and with REML/Blup in popcorn. Braz J Agricul Res. 48(11): 1464-1471.

Garbuglio DD, Branco MFJ, Cella M (2009) Genetic variability in S1 families from different maize populations. Acta Sci Agron. 31(2): 209-213.

Hallauer AR Miranda Filho JB (1988) Quantitative Genectic in Maize. Breeding, 2 ed, lowa State University Press, Ames, IA.

Harlan JR (1992) Crops and man. Madison: American Society of Agronomy, 284p.

Hull FH (1945) Recurrent selection for specific combining ability. J Amer. 37: 134-45.

Jones DF (1945) Heterosis resulting from degenerative changes. Genetics. 30(6): 527.

Jones DF (1918) The effect of inbreeding and crossbreeding upon development. Proceed Nat Acad Sci. 4(8): 246-250.

Junior CLS, Dos Santos MX, Magnavaca R, Gomes EE (1993) Genetic parameters in the interpopulation maize cross BR$105 \times$ BR-106 and their implications in selection. Braz J Agric Res. 28(4): 473-479.

Li CC (1975) Path analysis - a primer. Box wood: Pacific Grove, 346p.

Lima MWP, Souza EA, Ramalho MAP (2000) Procedure to select superior maize populations for inbred line extraction. Bragantia. 59(2): 153-158.

Lopes SJ, Lucio AD, Storck L, Damo HP, Brum B, Dos Santos VJ (2007) Path analysis on maize spikes characteristics related of the hybrid type. Rur Sci. 37(6): 1536-1542.

Lynch M, Bruce W(1998) Genetics and analysis of quantitative traits. vol. 1. Sunderland, MA: Sinauer.

Lush and Wright (1931) In. Cruz CD, Carneiro PCS, Regazzi AJ (2014) Modelos Biométricos Aplicados ao Melhoramento Genético, VOL. 2. Viçosa, 3a Ed. Editora UFV.

Magalhães PC, Durães FOM, Carneiro NP, Paiva N (2002) Fisiologia do milho. Sete Lagoas: Embrapa CNPMS. 23p. Circular Técnica, 22.

Mather K, Jinks JL (1984) Introdução à genética biométrica.2 ed. Wantage, Grã-Bretanha. 240p.

Morrison DF (1978) Multivariate statistical methods.2. Ed. Tokyo: McGraw Hill. 415p.

Nardino M, Baretta D, Carvalho IR, Olivoto T, Follmann DN, Szareski VJ, Ferrari M, De Pelegrin AJ, Konflanz VA, De Souza VQ (2016) Restricted maximum likelihood/best linear unbiased prediction (REML/BLUP) for analyzing the agronomic performance of corn. Afr J Agricul Res. 11(48): 4864-4872.

Nardino M, De Souza VQ, Baretta D, Konflanz VA, Follmann DN, Carvalho IR, Ferrari M, Caron BO, Schmidt D (2016) Partial diallel analysis among maize lines for characteristics related to the tassel and the productivity. Afr J Agric Res. 11(11): 974-982.

Nardino M, Baretta D, Carvalho IR, Follmann DN, Konflanz VA, Souza VQ, Costa De Oliveira A, Maia LC (2016) Correlações Fenotípica, Genética e de Ambiente entre caracteres de milho híbrido. Rer Bras de Biom. 34: 379/3394.

Nardino M, Carvalho IR, Baretta D, Follmann DN, Leschewitz R, Olivoto T, Caron BO, Oliveira AC, Maia L, Souza VQ (2016) Cycle segregation in crossings of landrace corn populations. Intern J Cur Res. 8: 37896-37900.
Nardino M, De Souza VQ, Baretta D, Konflanz VA, Carvalho IR, Follmann DN, Caron BO (2016) Association of secondary traits with yield in maize $F$ 1's. Rural Science. 46(5): 776-782.

Nardino M, Baretta D, Carvalho IR, Olivoto T, Follmann DN, Pelegrin AJ, Szareski VJ, Lautenchleger F, Rosa TC, Barbosa MH, Konflanz VA, Barros WS, Souza VQ (2018) Environment Stratification in the Evaluation of Corn Hybrids in Southern Brazil. J Agric Sci. v. 10, p. 333-342

Nogueira APO, Sediyama T, Sousa LB, Hamawaki OT, Cruz CD, Pereira DG, Matsuo E (2012) Path analysis and correlations among traits in soybean grown in two dates sowing. Biosc J. 28(6): 877-888.

Nunes GDS, Rezende GDSP, Ramalho MAP, Santos JD (2002) Implications of the genotype - environment in interaction effects on eucalyptus clone selection. Cerne. 8(1): 49-58.

Pacheco CAP, Gomes EE, Guimarães PEO, Dos Santos MX, Ferreira AS (1998) Genetic parameters estimatives in CMS42 and CMS-43 popcorn populations. Braz J Agric Res. 33(12): 1995-2001.

Palomino EC, Ramalho MAP, Ferreira DF (2000) Sample size for half-sib family evatuation in maize. Braz J Agric Res. 35(7): 1433-1439.

Paterniani E (1978) Melhoramento e produção do milho no Brasil. Campinas: Fundação Cargill, 650p.

Paterniani E, Campos MS (1999) Melhoramento do milho. In: Borém, A. (ed.). Melhoramento de espécies cultivadas. Viçosa: UFV, 429-486p.

Patterson HD, Thompson R (1971) Recovery of inter-block information when block sizes are unequal. Biometrics. 58: 545-554.

Paterniani MEAGZ, Guimarães $P$, Lüders RR, Gallo PB, Souza $A D$, Laborda PR, Oliveira KM (2008) Combining ability, genetic divergence among maize lines and correlation with heterosis. Bragantia. 67(3): 639-648.

Pegoraro DG, Barbosa Neto JF, Dal Soglio FK, Vacaro E, Nuss CN, Conceição LD (2002) Inheritance of the resistance to phaeosphaeria leaf spot in maize. Braz J Agric Res. 37(3): 329-36.

Pereira TCV, Schmit R, Haveroth EJ, Melo RCD, Coimbra JLM, Guidolin AF, Backes RL (2016) Reflex of genotype x environment interaction the genetic improvement of bean. Rur Sci. 46(3): 411-417.

Pupin S, Dos Santos AVDA, Zaruma DUG, Miranda AC, Da Silva PHM, Marino CL, Sebbenn ML, De Moraes MLT (2015) Productivity, stability and adaptability in open pollination progenies of Eucalyptus urophylla ST Blake. Sci Forest. 43(105): 127-134.

Ramalho MAP, Santos JP, dos Zimmermann MJO (1993) Genética quantitativa em plantas autógamas: Aplicações ao melhoramento do feijoeiro. Goiânia: ED. da UFG. 271p.

Ramalho M, Santos JB, Pinto CB, Souza EA, Gonçalvs FMA, Souza JC (2012) Genética na Agropecuária. 5 ed. Lavras: Lavras: UFLA. 565p.

Reis LS, Pereira MG, Silva RF, Meireles RC (2011) Effect of heterosis on sweet corn seed quality. Braz J Seeds. 33(2): 310-315.

Resende MDV de, Silva FFE, Azevedo CF (2014) Estatística matemática, biométrica e computacional: Modelos Mistos, Multivariados, Categóricos e Generalizados (REML/BLUP), Inferência Bayesiana, Regressão Aleatória, Seleção Genômica, QTL-GWAS, Estatística Espacial e Temporal, 
Competição, Sobrevivência. 1. ed. Visconde do Rio Branco: Suprema. v. 1. 881p.

Ribeiro JZ, de Almeida MIM (2011) Estratificação ambiental pela análise da interação genótipo $\mathrm{x}$ ambiente em milho. Braz J Agricul Res. 46(8):875-883, 2011.

Rosado AM, Rosado TB, Alves AA, Laviola BG, Bhering LL (2012) Simultaneous selection of eucalyptus clones based on yield, stability and adaptability. Braz J Agric Res.7(7): 964-971.

Rostagno HS (2011) Tabelas brasileiras para aves e suínos: composição de alimentos e exigências nutricionais. Viçosa: 3. ed UFV, 252p.

Santos J, Vencovsky R (1986) Genetic and phenotypic correlation between some agronomic characters of the bean (Phaseolus vulgaris L.). Sci Pract. 10(3): 265-272.

Santos OP, Carvalho IR, Nardino M, Olivoto T, Pelegrin AJ, Szareski VJ, Ferrari $M$, Nunes ACP, Demari GH, Lautenchleger F, Souza VQ, Maia LC (2018) Methods of adaptability and stability applied to Eucalyptus breeding. Pesquisa Agropecuária Brasileira. 53, p. 53-62.

Santos RC, Carvalho LP, Santos VF (2000) Path coefficient analysis for production componentes in peanut. Sci Agrotechnol. 24(1): 13-16.

Shull A (1912) Franklin The influence of inbreeding on vigor in Hydatinasenta. Biol Bull. 24(1): 1-13.

Shull GH (1909) A pure-line method of corn breeding. Am Breed Assoc Rep. 5: 51-59.

Soares MO, Miranda GV, Guimarães LM, Marriel IE, Guimarães CT (2011) Genetic parameters of a corn population at contrasting levels of nitrogen. J Sci Agron. 42(1): 168-174.

Szareski VJ, Carvalho IR, Kehl K, Levien AM, Nardino M, Dellagostin SM, Demari GH, Lautenchleger F, Villela FA, Pedo T, Souza VQ, Aumonde TZ (2018) Evaluation of the adaptability and stability of wheat genotypes using a phenotypic index of seed vigor. Pesquisa Agropecuária Brasileira. v. 53, p. 727-735.
Szareski VJ, Carvalho IR, Kehl K, Levien AM, Rosa TC, Barbosa MH, Demari GH, Pimentel JR, Troyjack C, Martinazzo EG, Souza VQ, Villela FA, Pedo T, Aumonde TZ (2018) Phenotypic and predicted genetic approaches for genotype ranking of wheat seed yield in Brazil. Genet Moler Res. 17, p. 1-13.

Szareski VJ, Carvalho IR, Kehl, Levien AM, Nardino M, Demari GH, Lautenchleger F, Souza VQ, Pedo T, Aumonde TZ (2017) Univariate, multivariate techniques and mixed models applied to the adaptability and stability of wheat in the Rio Grande do Sul State. Genet Mole Res. 16, p. 1-13.

Szareski VJ, Carvalho IR, Kehl K, Pelegrin AJ, Nardino M, Demari GH, Barbosa MH, Lautenchleger F, Smaniotto D, Aumonde TZ, Pedo T, Souza VQ (2018) Interrelations of characters and multivariate analysis in corn. J Agric Sci. 10, p. 187-194.

Teixeira FF (2008) Maize grown in Brazil and germplasm bank: a way of classifying genetic variability. Embrapa Milho e Sorgo. Comunicado técnico.

USDA - United States Departament Of Agriculture. Agriculture statistics. http://www.usda.gov/wps/portal/usda/usdahome. Acesso em 07 de dezembro de 2016.

Viegas GP, Miranda Filho JB (1978) Milho híbrido. In: Paternian (ed.) Melhoramento e Produção do Milho no Brasil. Edição da Fundação Cargil. 257 - 309p.

Vencovsky R (1978) Herança quantitativa. In: Paterniani E.ed. Melhoramento e produção de milho no Brasil. Piracicaba: Fundação Cargill. 122-201p.

Wright S (1921) Correlation and causation. J Agric Res. 20(1): 557-585.

Wright S (1923) The theory of path coefficients: a replay to Niles' criticism. Genet. 8(3): 239-255.

Yates (1931) In. Cruz CD, Carneiro PCS, Regazzi AJ (2014) Modelos Biométricos Aplicados ao Melhoramento Genético, VOL. 2. Viçosa, 3a Ed. Editora UFV. 